Review of

ECONOMICS

and

INSTITUTIONS
Review of Economics and Institutions

ISSN 2038-1379 DOI 10.5202/rei.v6i1.141

Vol. 6 - No. 1, Winter-Spring 2015 - Article 5

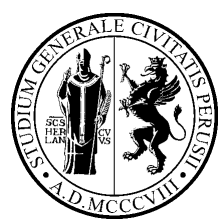

www.rei.unipg.it

\title{
Group Affiliation and Firms' Export Intensity: A Cross-Country Study
}

Fulvio Castellacci ${ }^{\bowtie}$

TIK Centre, University of Oslo

\begin{abstract}
The paper investigates whether the export intensity of business companies is greater for group-affiliated firms (GAFs) or for standalone firms (SAFs). The empirical analysis makes use of the World Bank Enterprise Survey for Latin American economies. The results show that GAFs have lower export intensity than SAFs. We also find that the difference between GAFs and SAFs' export intensity is much stronger in the service sectors, industries in which Latin American business groups have actively been investing in recent years. These results provide support to the groups as parasites theoretical view, which emphasizes the negative consequences that groups have for economic development.
\end{abstract}

JEL classification: F14; L10; L25; O54

Keywords: business groups, export performance, Latin America

Address: TIK Centre, University of Oslo, Postboks 1108, Blindern, 0317, Oslo - Norway (Phone: +47 22841628. Email: fulvio.castellacci@tik.uio.no).

\section{Recommended Citation}

Castellacci, F. (2015). Group Affiliation and Firms' Export Intensity: A Cross-Country Study. Review of Economics and Institutions, 6(1), Article 5. doi: 10.5202/rei.v6i1.141. Retrieved from http://www.rei.unipg.it/rei/article/view/141 


\section{Introduction}

Research in international economics and international business studies has in the last few years investigated how business companies respond to market liberalization and trade policy changes. The idea that firms respond differently to the process of trade liberalization, and that they differ in their internationalization ability, propensity and strategies, has been extensively investigated within the international business literature for some time already (Johanson and Vahlne, 1977). More recently, a new strand of research in international economics has developed models of firm heterogeneity and international trade, to investigate the reasons why only a small number of enterprises within each industry are able to export whereas most others are not (Melitz, 2003; Helpman et al., 2004).

An important aspect that has been almost entirely neglected in this field refers to the internationalization strategies of business groups. Groups are important economic agents in most developing economies, and particularly so in Latin America. How are Latin American business groups responding to the process of trade liberalization and market development that is currently ongoing in the region? Are they responding actively and reaping the benefits of a more open international market - or are they instead playing a more defensive strategy and only focusing on their own domestic markets in order to survive the strong competition from foreign MNEs?

The study of firms' internationalization strategies and performance is a neglected and unexplored area of research within the business groups literature (Aulakh et al., 2000; Carney et al., 2011). The few studies recently carried out on group internationalization have mostly focused on FDI (Tan and Meyer, 2010; Jean et al., 2011), and typically neglected export activities, which represent one of the most natural and important modes of entry that firms can adopt to penetrate foreign markets. Two notable exceptions are the papers by Hundley and Jacobson (1998) on the export strategies of Japanese keiretsu-affiliated firms, and Gubbi et al. (2009) on Indian companies in the pharmaceuticals sector.

Based on this research gap, this paper investigates one specific question focusing on the export activities of business groups: is the export performance of group affiliated firms (GAFs) greater or lower than that of standalone firms $(S A F S)$ ? We analyze this question by means of an empirical analysis based on the World Bank Enterprise Survey for all Latin American economies. The analysis has an explicitly comparative nature: (1) it compares groupaffiliated with independent companies; (2) it studies how this pattern differs across countries in the region; (3) it investigates how the affiliation-export relationship differs between manufacturing industries and the service sectors.

The econometric results show that GAFs have lower export intensity than SAFs, and that the difference between GAFs and SAFs' export intensity 
is much stronger in the service sectors, a branch of the economy in which business groups in many countries in the region have actively been investing in recent years. The general result that business groups' export performance is on average lower than that of independent companies questions the role of groups for economic development, because it implies that business groups do not actively contribute to the process of export-led growth and economic development in Latin American economies.$^{1}$

The paper is organized as follows. Section 2 outlines the theory and hypotheses; section 3 presents the data, indicators and some descriptive statistics; section 4 points out the econometric methodology; section 5 presents the empirical results; and section 6 summarizes the main conclusions and implications of the work.

\section{Theory and Hypotheses}

A new strand of research in international economics has in the last few years investigated how business companies respond to market liberalization. In traditional mainstream international trade models, all firms within the same industry are supposed to engage in trade activities in the same way and to the same extent - depending on the country's resource endowments and comparative advantages. However, recent firm heterogeneity models have challenged the conventional wisdom and investigated the reasons why, as shown by empirical evidence, only a small number of enterprises within each industry are able to export whereas most others are not (Melitz, 2003; Helpman et alia, 2004).

The main idea of this approach is that engaging in international activities is costly, since business firms typically face substantial sunk costs if they want to enter foreign markets. Hence, only enterprises endowed with a sufficient level of resources and capabilities will be able to sustain the sunk costs of internationalization, whereas most other firms in the same sector will not be able to do so, and will only produce for the domestic market (Mayer and Ottaviano, 2007). Empirical studies in this recent strand of the international economics literature have provided a stylized characterization of firm heterogeneity, and mostly focused on enterprises' differences in terms of their size and productivity levels, which, despite their importance, represent generic factors measuring companies' capabilities and resources.

The idea that firms respond differently to a process of trade liberalization, and that they differ in their internationalization ability, propensity and strategies, has also been extensively investigated within the international business literature (e.g. Johanson and Vahlne, 1977). Much of this research

1 The present article is based upon and extends further one of the chapters in Bull et al. (2014). This book presents a comprehensive analysis of economic and political strategies of business groups in six Central American economies, and discusses their role for economic development and institutional change in the region. 
has adopted the resource-based view of the firm, according to which it is important to distinguish between resources and capabilities (Penrose, 1959; Wernerfelt, 1984). Resources are stocks of production factors that a firm possesses (e.g. physical and human capital), whereas capabilities represent its ability to manage these resources in order to create products and services. Guillen (2000) presents a seminal study on company internationalization based on the resource-based view of the firm, investigating whether the emergence and success of business groups in emerging economies may be explained by the superior set of resources and capabilities they possess.

Guillen's (2000) study represents however an exception: most of the literature on companies' internationalization, both in the international economics and international business fields, has so far neglected the study of how firms' ownership and group affiliation shape the relationship between enterprises characteristics (resources, capabilities and strategies) and their international performance. Notable exceptions are the few studies that have recently investigated outward FDI activities of business groups (Tan and Meyer, 2010; Jean et al., 2011), and the export performance of groupaffiliated firms (Hundley and Jacobson, 1998; Gubbi et al., 2009).

The scarcity of studies on the internationalization activities of business groups contrasts with the large amount of research that has been carried out in the last few years on firm internationalization in more general terms. This research gap calls for further studies to investigate whether groupaffiliated firms (GAFs) have a higher, or lower, internationalization ability and propensity than standalone firms (SAFs). This issue is relevant to understand how these two different types of companies respond to processes of institutional change and trade liberalization in developing economies, and what the possible implications for economic development are.

It is not easy to provide an answer to the question on whether the export performance of GAFs is higher or lower than SAFs. Two different conceptual views are typically outlined in the business group literature, and each of them, when extended to the study of firm internationalization, would lead to formulate a different prediction as to the relative export performance of GAFs versus SAFs.

\subsection{GAFs Have Better Export Performance than SAFs}

One dominant approach in the business group literature argues that groups are paragons: they play an important function for economic development in emerging economies, because they compensate and make up for market failures and institutional weaknesses (Leff, 1978; Khanna and Palepu, 1997; Khanna and Yafeh, 2007; Carney et al., 2011). This view is often referred to as the institutional voids thesis (for a more extensive presentation of this approach, see Castellacci, 2013a).

The institutional voids thesis is closely related to, and based on, trans- 
action costs economics (Williamson, 1975). The main idea is that business groups have a better financial and economic performance than unaffiliated companies because their organizational structure and internal network make it possible to exploit a richer set of resources, and to decrease and partly avoid the high transaction costs that characterize the inefficient market context that is typical of less developed economies.

This general argument has obvious and direct implications for the export activities of group-affiliated firms. If it is true that GAFs have greater internal resources and capabilities than SAFs because of their organizational structure and network capabilities, it would be reasonable to expect that the former will be better able to overcome entry barriers in foreign markets and sustain the sunk costs related to international activities. Specifically, the general hypothesis of a greater export performance of GAFs vis-a-vis SAFs is supported by the following arguments.

(1) Finance. As often pointed out in the business group literature, GAFs have more easily access to financial resources within the group. They may in this way have a higher propensity to invest in international activities, and share the related risks and sunk costs with other companies of the same group.

(2) Skilled labor. Business groups may also be able to achieve a more efficient internal allocation of labor resources, and increase their workers' skills and human capital level by means of internal training courses and activities. The superior human capital and managerial resources available to GAFs support their innovative activities and product quality, and hence their international performance and competitiveness.

(3) Home market. When the home market is not well developed, as it is typically the case in less developed economies, GAFs may overcome the lack of reliable suppliers and advanced users by purchasing from, and selling to, other companies belonging to the same group. Hence, within-group vertical integration may partly substitute for the lack of a good home market (Mahmood et al., 2011).

(4) Information on foreign markets. A recent strand of literature on "networks in international trade" argues that groups have more easily access to knowledge and information about foreign markets and distribution network abroad, and may in this way reduce the high sunk costs that exporting firms typically face (Casella and Rauch, 2002; Jean et al., 2011; Bastos and Silva, 2012; Castellacci, 2013b).

(5) Contract enforcement. If legal institutions and contract enforcing mechanisms are weak, as it is often the case in developing economies, business firms face high transaction costs, and particularly so in relation to 
their international sales. Group affiliation may decrease these transaction costs and favor enforcements of contracts in international trade (Rauch, 2001).

(6) Links to foreign MNEs. In an economic environment characterized by weak contract enforcement rules and inefficient legal institutions, foreign MNEs are likely to regard domestic business groups as more reliable commercial partners than other local companies. Therefore, GAFs can more easily develop collaborations with foreign firms and MNEs, and use this channel to build up their own distribution network abroad and to foster learning through foreign spillovers (Mahmood and Mitchell, 2004; Lamin, 2006).

Taken together, these six arguments all point in the same direction: extending the view of the institutional voids thesis and the group as paragons approach, it would be reasonable to expect that affiliated firms have a greater ability and propensity to sell their products abroad through international trade than unaffiliated companies.

Proposition 1a: GAFs have higher export intensity than SAFs.

\subsection{GAFs Have Worse Export Performance than SAFs}

A different approach in the business group literature argues that groups are parasites: they play a negative function in developing economies for two main reasons. First, due to their strong market power and political connections, groups are often able to erect entry barriers in domestic industries to prevent other firms to enter the market. This reduces the level of market competition, having negative consequences in terms of price dynamics, domestic consumption and welfare. Further, entry barriers reduce firm heterogeneity in the domestic market and may in this way hamper the entry of new innovative firms (Hannan and Freeman, 1989; Mahmood and Mitchell, 2004).

Secondly, groups are often inefficient and rent-seeking organizations. The literature on agency theory and corporate governance points out that groups have often concentrated ownership characterized as control pyramids, in which a family firm controls several listed companies. This type of structure leads to the separation of ownership and control and thereby creates important agency problems. The effects of these agency problems are capital misallocations and a lower level of efficiency in the national economy (Morck et al., 2005).

Both of these arguments emphasize the negative effects that groups may have on economic development. This view may also have direct implications in terms of the internationalization and export performance of business groups. If groups decrease the market efficiency of the economy, because of both their high market power and the related agency problems, 
then it would be reasonable to expect that group-affiliated companies have a lower internationalization ability and/or propensity than unaffiliated enterprises. Six specific arguments develop this hypothesis.

(1) Exploration ability. Because of their hierarchical structure, GAFs may lack the flexibility to explore advanced knowledge and opportunities available in the external environment, and particularly in foreign markets (Gubbi et al., 2009).

(2) Agency problems. Agency issues related to the separation of ownership and control may lead to inefficiencies, and in particular make groups' internationalization strategies less focused, effective and competitive than those of standalone enterprises.

(3) Within-group coordination. If international activities and strategies are coordinated at the group level, export activities will be concentrated only in a few companies of a group, whereas other affiliated companies may be forced to play the role of domestic producers or suppliers of intermediate products for the few exporting companies. While this coordination strategy may be advantageous for the group as a whole, this also implies that some GAFs that could in principle sale their products in international markets are not able to do so because of this group-level internationalization strategy. This may result in a lower average export level of GAFs.

(4) Domestic network. GAFs may not only have a minor capability to export, as the previous arguments suggest, but also a lower propensity (willingness, interest) to engage in export activities. One main reason for this is that the benefits of affiliation, related to companies' network, political and social relations, are mainly domestic (Granovetter, 1995; Gubbi et al., 2009). So, focusing on the domestic market and avoiding to engage in international competition may simply be a more rewarding and less risky strategy for oligopolistic GAFs.

(5) Within-group trade. Another reason why GAFs are more domestically oriented than SAFs is because affiliated companies may find it convenient to trade with other firms within the same domestic group instead of engaging in international competition. Within-group trade contributes to protect GAFs from foreign competition (Hundley and Jacobson, 1998; Tan and Meyer, 2010).

(6) High FDI propensity. A different reason why GAFs may have lower export propensity than SAFs is related to the literature on firms' choice between different modes of internationalization, and in particular between export and FDI. The proximity concentration trade-off model of trade and FDI (Helpman et al., 2004; Castellacci, 2013c) argues that 
the most productive companies within each industry will prefer to internationalize through FDI rather than export, because in this way they may avoid the sunk costs related to international trade activities as well as transportation costs. In particular, GAFs that are part of a regional / international network are better able to set up affiliates abroad, thanks to the financial, human and other intangible resources available within the group (Belderbos and Sleuwagen, 1996). According to this view, then, GAFs regard internationalization as an important objective, but they find it more convenient to pursue it through FDI rather than by export sales.

On the whole, these six arguments all lead to the same prediction that affiliated firms have lower export performance than unaffiliated companies. But, as indicated above, they do so for different reasons. Points (1) to (3) argue that GAFs have a lower capability to engage in international activities; points (4) and (5) suggest that affiliated companies may have a minor propensity (willingness, interest) to internationalize; whereas point (6) contends that GAFs are actually highly engaged in international activities, but their preferred mode of entry into foreign markets is through FDI instead of export and international trade. Despite these conceptual differences, however, all six arguments lead to the following empirical prediction:

Proposition 1b: GAFs have lower export intensity than SAFs.

\section{Data and Indicators}

The paper carries out an empirical analysis of the contrasting theoretical predictions outlined in the previous section. We carry out a comparative analysis, where group-affiliated companies can be compared to unaffiliated firms, and these patterns can also be investigated across countries as well as across sectors. The econometric analysis in this paper is based upon the World Bank Enterprise Surveys (WBES) database. The WBES database is a well-known and widely used data sources for firm-level analyses on business and economic development in emerging economies. It is a large survey dataset of several thousand business firms in nearly all developing countries, and contains information on companies' characteristics, strategies, economic performance, as well as their perceptions of the institutional, policy and economic environment in which they operate. The WBES follows a stratified random sampling with replacement, based on firm size, business sector and geographic region as the main strata, which ensures representativeness of the results within each country. The survey questionnaire follows a standard template, in order to ensure cross-country comparability of the results. We focus here on the most recent wave of the WBES, the one referring to the period 2010-2011. A key characteristic of the WBES dataset is that it contains information on firms' ownership. From this information, we 
are able to identify which firms in the database that are part of a domestic group (GAFs), and distinguish these from the sample of standalone firms (SAFs; see Appendix). This information is very valuable from the point of view of the business groups literature. So far, group identification has in fact been a controversial and difficult task for empirical works in this field (Khanna, 2000; Yafeh, 2005), and the information on group affiliation has often been limited to enterprises within a specific country.

The study focuses on 20 Latin American countries, covering nearly the whole region. This makes it possible to analyze firm-level patterns in a cross-country comparative perspective, and investigate whether the behavior, strategies and performance of business companies in a specific national economy differs systematically from enterprises in other more advanced economies in the region. The whole sample contains a total number of around 13000 firms, covering all sectors of economic activity, and in particular all manufacturing and service sectors. The availability of micro data on all industrial sectors also enables a comparison of groups' strategies and internationalization patterns in different branches of the economy.

Table 1 presents the list of 12 indicators that we have calculated on the WBES dataset, along with their definition and descriptive statistics. The first indicator, EXPORT, will be used as the dependent variable in the econometric study. It indicates that the export intensity of Latin American firms is on average $6.4 \%$ (i.e. around $6 \%$ of companies' total revenues comes from the sales of goods and services to foreign countries). The next indicator, GAF, is the main explanatory variable in the study: it is a dummy variable that identifies the companies that are part of a group. The descriptive statistics show that $19 \%$ of the companies in the WBES sample are affiliated to a domestic group, whereas the other enterprises are either part of a foreign MNE $(8 \%)$, or unaffiliated (independent) firms (the remaining 73\%). All other variables listed in Table 1 measure firm-specific characteristics that, according to the internationalization literature, may affect the export performance of business companies (the next section will elaborate further on the specific role of each of these control factors).

Table 2 reports the mean of the two key variables of the study - EXPORT and GAF - for each of the 20 countries for which we have available data. The cross-country comparison indicates that the export intensity does not vary substantially across countries in Latin America: Peru, Argentina, Costa Rica, Guatemala, Uruguay and Guyana are the economies with the highest export intensity (around 10\%), whereas Ecuador, Honduras, Panama, Brazil and Venezuela are the countries with the lowest export intensity $(3 \%$ or lower). In international perspective and comparing to what is the case in other regions of the world, the average export intensity of Latin American companies is quite low, and the cross-country differences among countries in the region are rather limited. In line with much of the recent literature in international economics and international business studies, these patterns 
Table 1 - Indicators from the WBES Database (all Latin American Countries): Definition and Descriptive Statistics

\begin{tabular}{|c|c|c|c|c|c|c|}
\hline Indicator & Definition & Mean & $\begin{array}{l}\text { Std. } \\
\text { Dev. }\end{array}$ & Min & Max & Obs. \\
\hline EXPORT & $\begin{array}{l}\text { Export intensity: export sales as a share of total sales of the } \\
\text { firm }\end{array}$ & 6.42 & 18.73 & 0 & 100 & 12900 \\
\hline GAF & Group affiliation (dummy) & 0.19 & 0.399 & 0 & 1 & 12929 \\
\hline MNE & Foreign MNEs affiliation (dummy) & 0.08 & 0.281 & 0 & 1 & 12929 \\
\hline SIZE & Size class (employees; categorical 0-3 indicator) & 1.92 & 0.79 & 0 & 3 & 12929 \\
\hline AGE & Age of the company & 25.36 & 19.85 & 0 & 340 & 12816 \\
\hline QUALITY & ISO quality certification (dummy) & 0.24 & 0.43 & 0 & 1 & 12413 \\
\hline PRODUCTIVITY & Log of labor productivity & 1.85 & 1.06 & -5.73 & 13.41 & 10410 \\
\hline ICT & High-speed internet connection (dummy) & 0.85 & 0.35 & 0 & 1 & 10967 \\
\hline DIVERSIF & $\begin{array}{l}\text { Product diversification: Share of sales from the firm's main } \\
\text { product line }\end{array}$ & 69.98 & 26.59 & 0 & 100 & 12784 \\
\hline URBAN & $\begin{array}{l}\text { Size of the city in which the firm is located (categorical 1-5 } \\
\text { indicator) }\end{array}$ & 2.02 & 1.26 & 1 & 5 & 12929 \\
\hline OBST_TRANSPORT & $\begin{array}{l}\text { Transport as an important obstacle for the enterprise } \\
\text { (categorical 0-4 indicator) }\end{array}$ & 1.55 & 1.33 & 0 & 4 & 12809 \\
\hline OBST_REGULATION & $\begin{array}{l}\text { Trade regul. as an important obstacle for the enterprise } \\
\text { (categorical 0-4 indicator) }\end{array}$ & 1.23 & 1.30 & 0 & 4 & 11548 \\
\hline
\end{tabular}

Table 2 - Export Intensity and Group Affiliation: Descriptive Statistics by Country

\begin{tabular}{ccccccccccc}
\hline \hline & Argentina & Bolivia & Chile & Colombia & Costa Rica & $\begin{array}{c}\text { Dominican } \\
\text { Republic }\end{array}$ \\
\hline EXPORT & 9.67 & 4.68 & 7.12 & 6.32 & 10.01 & 6.65 & 2.83 & 8.61 & 9.74 & 12.52 \\
GAF & 0.23 & 0.23 & 0.24 & 0.01 & 0.10 & 0.09 & 0.14 & 0.26 & 0.10 & 0.25 \\
Observations & 1052 & 362 & 1033 & 942 & 538 & 360 & 366 & 360 & 590 & 165 \\
& & & & & & & & & & \\
\hline & Honduras & Jamaica & Mexico Nicaragua & Panama & Paraguay & Peru & Brazil & Uruguay & Venezuela \\
\hline EXPORT & 3.70 & 3.39 & 5.78 & 4.06 & 1.19 & 5.86 & 11.5 & 2.39 & 10.3 & 0.62 \\
GAF & 0.14 & 0.09 & 0.19 & 0.15 & 0.11 & 0.12 & 0.15 & 0.46 & 0.08 & 0.31 \\
Observations & 360 & 376 & 1480 & 336 & 365 & 361 & 1000 & 1802 & 607 & 320 \\
\hline \hline
\end{tabular}

Source: WBES Survey Database

would suggest that the major determinants of export intensity are related to firm-specific resources, capabilities and organizational structure rather than country-specific institutions and macroeconomic environment. Thus, the remainder of this paper will not emphasize cross-country differences, but rather focus on the firm-level determinants of export activities.

\section{Econometric Model}

The econometric analysis seeks to investigate the determinants of the export intensity of firms in Latin America. The analysis has three specific objectives: (1) to empirically test the contrasting propositions noted above (see section 2) about the role of group affiliation on enterprises' export performance; (2) to investigate the extent to which the affiliation-export rela- 
tionship differs across countries in Latin America; (3) and to study whether this relationship differs between manufacturing and service sectors. The econometric model has the following specification (for the definition of the indicators, see Table 1 above).

$$
\begin{aligned}
\text { EXPORT }_{i} & =\alpha+\beta G A F_{i}+\sigma M N E_{i}+\omega S I Z E_{i}+\gamma A G E_{i}+\delta \text { QUALITY }_{i} \\
& +\kappa P R O D U C T I V I T Y_{i}+\tau I C T_{i}+\varsigma \text { DIVERSIF } F_{i}+\varphi U R B A N_{i} \\
& +\eta O B S T \_T R A N S P O R T_{i}+\theta O B S T \_R E G U L A T I O N_{i} \\
& +\lambda S_{i}+\rho C_{i}+\epsilon_{i} .
\end{aligned}
$$

EXPORT represents the export intensity of each company in the sample, and it is the dependent variable in the regressions. Among the explanatory variables on the right-hand side of the equation, GAF is the main variable of interest for this study. It is the dummy variable indicating whether a firm is affiliated to a business group. As explained in section 2, it is not possible to formulate a clear expectation on the sign of the effect of GAF on EXPORT. On the one hand, group-affiliated firms may have a stronger internationalization propensity and higher export performance than unaffiliated companies (proposition 1a): the sign of the estimated $\beta$ coefficient should hence be positive. By contrast, a different set of arguments contend that GAFs may have lower export intensity than SAFs (proposition 1b): the sign of the estimated $\beta$ coefficient would in this case be positive. The estimation of the sign of the $\beta$ coefficient in equation 1 does therefore represent the main focus of our analysis. In some of the regressions, we will also interact the GAF variable with country-specific and sector-specific dummy variables, in order to see whether the affiliation-export relationship differs between Central American and South American countries, on the one hand, and between manufacturing and service sectors, on the other.

Regarding the other explanatory factors in equation 1, they represent control variables that have previously been identified as important in the international economics and international business literature, and that it is therefore relevant to take into consideration. The MNE variable is a dummy for firms that are affiliated to a foreign multinational enterprise. The variable is expected to be positive in the estimations, since MNEs often use their affiliates in developing economies as a platform to produce at lower costs and thereby export their products and services to more developed markets (this strategy is what the international economics literature calls export-platform FDI; see Ekholm et al., 2003). Next, SIZE and PRODUCTIVITY are the two key variables emphasized in recent models of firm heterogeneity and international trade (Melitz, 2003; Helpman et al., 2004). They are expected to be positive in the regressions, since firms with a greater size and productivity are supposedly better able at paying sunk internationalization costs and thus overcome entry barriers in foreign markets. QUALITY and ICT investigate whether the availability of an internationally recognized quality certification (a proxy for product quality), on the one hand, 
and Internet facilities (ICT infrastructure), on the other, contribute to sustain export performance. The DIVERSIF variable measures the degree to which a firm concentrates its sales on one main product line or rather spreads it over a larger and more diversified set of products. A positive estimated sign for this variable would then indicate that firms with a more concentrated and less diversified product range have higher export intensity. The regressor AGE controls whether the age of the firm has an effect on its export intensity. The variable URBAN measures the size of the city in which the company is located. A positive estimated sign for this variable would indicate that companies located in larger cities are on average more export intensive than firms located in smaller towns or rural areas (a relationship related to so-called urban or agglomeration economies). The control variables OBST_TRANSPORT and OBST_REGULATION measure the effects of transportation costs and trade regulation on companies' export intensity. A positive sign of these variables would indicate that exporting firms consider these two factors as important obstacles for their business activities. Finally, equation 1 also includes a set of dummies for all industrial sectors $(S)$ and all countries $(C)$ in the sample.

We estimate equation 1 on the WBES dataset described in the previous section. The data is cross-sectional and refers to the period 2010-2011. We estimate the regression model by means of a Tobit with instrumental variables estimation method (Tobit IV). The tobit model takes into account the fact that the dependent variable, export intensity, is a continuous indicator that is defined in the 0-1 interval (i.e. a firm's export intensity, calculated as a share of its total revenues, is not defined below the value $0 \%$ and above the ceiling $100 \%$ ). Further, an instrumental variable approach is used to take into account of the possible endogeneity of two of the explanatory factors: PRODUCTIVITY and GAF. The endogeneity of the productivity variable in export regressions is a well-known and widely debated issue in the recent applied literature in international economics. Besides having a direct positive effect on export, in fact, a firm's productivity may be further enhanced when the company operates in foreign markets due to international competition, learning and spillover effects. For different reasons, also the GAF explanatory variable may be considered endogenous, as previously pointed out in the international business literature: firms that have a better export performance may be more likely to have a strong international network, reputation and visibility, and may therefore be more likely to be invited to join a larger business group (this is the so-called "winner picking" issue, see Khanna, 2000: 752). To take into account the possible endogeneity of the productivity and group-affiliation indicators, we make use of three instrumental variables: (i) Establishment dummy (whether the company is a secondary establishment or main headquarter); (ii) OBST_TAX: whether the company considers "tax administration" as an important obstacle for the enterprise (categorical 0-4 indicator); (iii) OBST_PERMITS: whether the firm 
regards "business permits" as an important obstacle for the enterprise (categorical 0-4 indicator). These instruments are correlated to the PRODUCTIVITY and GAF variables in the first-stage regression, but uncorrelated with the export intensity dependent variable in the second-stage.

\section{Results}

Table 3 presents the regression results. Regressions 1, 2 and 5 estimate the model for the whole sample of Latin American countries (7183 companies), whereas regressions 3, 4, 6 and 7 estimate the model separately for firms in South America and Central America (5718 and 1465 observations, respectively). We first discuss briefly the results for the control variables, and then those in relation to the GAF dummy variable, which is the main focus of this study.

The foreign MNE variable is much larger in the regressions for the Central American sample (see columns 4 and 7) than those for the South American countries (columns 3 and 6 . This positive and large coefficient for the Central American sample would suggest that foreign MNEs from advanced economies use their affiliates in Central American countries as a platform to produce at lower costs and thereby export their products and services to more developed markets, in line with the theory of export-platform FDI (Ekholm et al., 2003). However, none of these estimations is statistically significant at conventional levels, so this finding in relation to the foreign MNE variable should be interpreted with caution.

The two key variables emphasized in recent models of firm heterogeneity and international trade are, as previously noted, SIZE and PRODUCTIVITY. The SIZE variable is as expected positive in the regressions, indicating that larger firms have in general availability of a greater amount of resources and managerial capabilities and they are therefore better able at overcoming entry barriers in foreign markets and exporting their products and services overseas (Melitz, 2003; Helpman et al., 2004). The estimated coefficient for the firm size indicator is also much larger for the Central American sample, pointing this out as a crucial factor of export competitiveness for business enterprises in this region. By contrast, the PRODUCTIVITY variable does not turn out to be significant in any of the regressions, differently from what is typically found in empirical analysis of export determinants for more advanced economies (Mayer and Ottaviano, 2007).

Next, the two variables QUALITY and ICT are both positive and significant in all the estimations. They confirm that firms with a higher product quality, on the one hand, and ICT infrastructure, on the other, have on average higher export intensity. It is also interesting to observe that the estimated coefficients for both of these variables are substantially larger for companies in Central American economies, indicating the crucial importance of product quality and ICT infrastructures as factors of international 
Table 3 - Estimation Results for equation 1. Dependent Variable: EXPORT (Export Intensity). Estimation Method: Tobit with Instrumental Variables

\begin{tabular}{|c|c|c|c|c|c|c|c|}
\hline Sample & $\begin{array}{c}\text { (1) } \\
\text { Latin America }\end{array}$ & $\begin{array}{c}\text { (2) } \\
\text { Latin America }\end{array}$ & $\begin{array}{c}\text { (3) } \\
\text { South America }\end{array}$ & $\begin{array}{c}\text { (4) } \\
\text { Central America }\end{array}$ & $\begin{array}{c}\text { (5) } \\
\text { Latin America }\end{array}$ & $\begin{array}{c}\text { (6) } \\
\text { South America }\end{array}$ & $\begin{array}{c}\text { (7) } \\
\text { Central America }\end{array}$ \\
\hline GAF & $\begin{array}{c}-20.23 \\
(2.20)^{* *}\end{array}$ & & $\begin{array}{c}-23.14 \\
(2.55)^{* *}\end{array}$ & $\begin{array}{l}63.77 \\
(0.78)\end{array}$ & & & \\
\hline $\mathrm{GAF}^{*}$ Central America & & $\begin{array}{l}-4.82 \\
(0.79)\end{array}$ & & & & & \\
\hline GAF * South America & & $\begin{array}{c}-9.25 \\
(3.62)^{* * *}\end{array}$ & & & & & \\
\hline GAF * MANUF & & & & & $\begin{array}{c}-6.69 \\
(2.52)^{* *}\end{array}$ & $\begin{array}{c}-7.98 \\
(3.05)^{* * *}\end{array}$ & $\begin{array}{l}28.13 \\
(1.04)\end{array}$ \\
\hline GAF * SERVICES & & & & & $\begin{array}{c}-12.93 \\
(2.89)^{* * *}\end{array}$ & $\begin{array}{c}-13.05 \\
(2.79)^{* * *}\end{array}$ & $\begin{array}{l}31.05 \\
(0.92)\end{array}$ \\
\hline MNE & $\begin{array}{l}-0.17 \\
(0.03)\end{array}$ & $\begin{array}{c}2.91 \\
(0.66)\end{array}$ & $\begin{array}{l}-0.93 \\
(0.18)\end{array}$ & $\begin{array}{l}36.25 \\
(1.09)\end{array}$ & $\begin{array}{c}2.86 \\
(0.64)\end{array}$ & $\begin{array}{c}2.28 \\
(0.51)\end{array}$ & $\begin{array}{l}28.62 \\
(1.20)\end{array}$ \\
\hline SIZE & $\begin{array}{c}15.81 \\
(8.28)^{* * *}\end{array}$ & $\begin{array}{c}16.21 \\
(8.94)^{* * *}\end{array}$ & $\begin{array}{c}16.61 \\
(9.72)^{* * *}\end{array}$ & $\begin{array}{c}32.73 \\
(2.05)^{* *}\end{array}$ & $\begin{array}{c}16.14 \\
(8.77)^{* * *}\end{array}$ & $\begin{array}{c}16.67 \\
(9.97)^{* * *}\end{array}$ & $\begin{array}{c}30.69 \\
(2.35)^{* *}\end{array}$ \\
\hline AGE & $\begin{array}{l}-0.02 \\
(0.58)\end{array}$ & $\begin{array}{l}-0.03 \\
(0.94)\end{array}$ & $\begin{array}{c}0.01 \\
(0.18)\end{array}$ & $\begin{array}{l}-0.34 \\
(1.10)\end{array}$ & $\begin{array}{l}-0.03 \\
(0.91)\end{array}$ & $\begin{array}{r}-0.004 \\
(0.11)\end{array}$ & $\begin{array}{l}-0.28 \\
(1.19)\end{array}$ \\
\hline QUALITY & $\begin{array}{c}22.02 \\
(6.83)^{* * *}\end{array}$ & $\begin{array}{c}23.20 \\
(7.28)^{* * *}\end{array}$ & $\begin{array}{c}20.41 \\
(7.03)^{* * *}\end{array}$ & $\begin{array}{c}63.34 \\
(2.46)^{* *}\end{array}$ & $\begin{array}{c}23.00 \\
(7.57)^{* * *}\end{array}$ & $\begin{array}{c}21.13 \\
(7.56)^{* * *}\end{array}$ & $\begin{array}{c}59.24 \\
(2.91)^{* * *}\end{array}$ \\
\hline PRODUCTIVITY & $\begin{array}{l}19.73 \\
(1.07)\end{array}$ & $\begin{array}{c}9.46 \\
(0.59)\end{array}$ & $\begin{array}{l}14.98 \\
(0.98)\end{array}$ & $\begin{array}{l}-161.1 \\
(1.13)\end{array}$ & $\begin{array}{l}10.22 \\
(0.62)\end{array}$ & $\begin{array}{c}6.41 \\
(0.46)\end{array}$ & $\begin{array}{c}-134.02 \\
(1.24)\end{array}$ \\
\hline ICT & $\begin{array}{c}24.08 \\
(5.36)^{* * *}\end{array}$ & $\begin{array}{c}25.09 \\
(5.86)^{* * *}\end{array}$ & $\begin{array}{c}20.17 \\
(4.19)^{* * *}\end{array}$ & $\begin{array}{c}51.59 \\
(2.89)^{* * *}\end{array}$ & $\begin{array}{c}24.97 \\
(5.75)^{* * *}\end{array}$ & $\begin{array}{c}21.02 \\
(4.46)^{* * *}\end{array}$ & $\begin{array}{c}49.98 \\
(3.24)^{* * *}\end{array}$ \\
\hline DIVERSIF & $\begin{array}{c}0.17 \\
(5.73)^{* * *}\end{array}$ & $\begin{array}{c}0.17 \\
(6.16)^{* * *}\end{array}$ & $\begin{array}{c}0.17 \\
(5.35)^{* * *}\end{array}$ & $\begin{array}{l}-0.066 \\
(0.27)\end{array}$ & $\begin{array}{c}0.17 \\
(6.15)^{* * *}\end{array}$ & $\begin{array}{c}0.18 \\
(5.84)^{* * *}\end{array}$ & $\begin{array}{l}-0.04 \\
(0.21)\end{array}$ \\
\hline URBAN & $\begin{array}{c}0.98 \\
(1.24)\end{array}$ & $\begin{array}{c}1.27 \\
(1.69)^{*}\end{array}$ & $\begin{array}{c}1.26 \\
(1.55)\end{array}$ & $\begin{array}{c}8.50 \\
(1.20)\end{array}$ & $\begin{array}{c}1.23 \\
(1.65)^{*}\end{array}$ & $\begin{array}{c}1.34 \\
(1.69)^{*}\end{array}$ & $\begin{array}{c}6.92 \\
(1.35)\end{array}$ \\
\hline OBST_TRANSPORT & $\begin{array}{c}-3.14 \\
(4.08)^{* * *}\end{array}$ & $\begin{array}{c}-2.85 \\
(3.98)^{* * *}\end{array}$ & $\begin{array}{c}-3.84 \\
(5.25)^{* * *}\end{array}$ & $\begin{array}{c}9.57 \\
(1.22)\end{array}$ & $\begin{array}{c}-2.88 \\
(4.00)^{* * *}\end{array}$ & $\begin{array}{c}-3.67 \\
(5.19)^{* * *}\end{array}$ & $\begin{array}{c}7.95 \\
(1.35)\end{array}$ \\
\hline OBST_REGULATION & $\begin{array}{c}9.14 \\
(12.87)^{* * *}\end{array}$ & $\begin{array}{c}8.98 \\
(13.24)^{* * *}\end{array}$ & $\begin{array}{c}9.32 \\
(12.48)^{* * *}\end{array}$ & $\begin{array}{c}4.28 \\
(0.86)\end{array}$ & $\begin{array}{c}8.98 \\
(13.23)^{* * *}\end{array}$ & $\begin{array}{c}9.19 \\
(12.66)^{* * *}\end{array}$ & $\begin{array}{c}5.06 \\
(1.28)\end{array}$ \\
\hline Observations & 7183 & 7183 & 5718 & 1465 & 7183 & 5718 & 1465 \\
\hline
\end{tabular}

Notes: All regressions include industry dummies and country dummies. IV Tobit estimation method. Endogenous variables: (i) GAF; (ii) PRODUCTIVITY. Instrumental variables: (i) Establishment dummy; (ii) OBST_TAX: Tax administration as an important obstacle for the enterprise (categorical 0-4 indicator); (iii) OBST_PERMITS: Business permits as an important obstacle for the enterprise (categorical 0-4 indicator). Source: WBES Survey Database 
competitiveness for companies in the region.

The DIVERSIF variable turns out to be positive and significant in most of the regressions (except from those for the Central American sample). Since this indicator is defined as the degree to which a firm concentrates its sales on one main product line, the positive sign for this variable points out that, on average, firms with a more concentrated and less diversified product range have higher export intensity. This suggests that industrial specialization and the ability to focus on a restricted set of core competencies are key strategies of international competitiveness (Prahalad and Hamel, 1990; Aulakh et al., 2000).

The AGE control variable is not significant in any of the regressions, so we are not able to identify any precise relationship between the age of the firm and its export performance. On the other hand, the variable URBAN is positive and significant in most of the estimations, confirming the urban (or agglomeration) economies argument that companies located in larger cities may strengthen their competitiveness through spillover effects, and hence achieve better economic and export performance than firms located in smaller towns or rural areas.

The last two control variables reported in the bottom of Table 3 are OBST TRANSPORT and OBST_REGULATION, measuring the effects of transportation costs and trade regulation on companies' export intensity. The estimated coefficient for the former variable is negative, whereas the one for the latter is positive. This means that exporting firms in Latin America do not regard transportation costs and geographical distance as a main obstacle for their business activities, but they do consider trade policy and regulation as an important hampering factor.

We now shift the focus to the results for the variable of our main interest, GAF, the dummy indicating whether a firm is affiliated to a business group or an independent company. As explained above, the sign of the estimated $\beta$ coefficient provides an answer to the primary question investigated in this paper - is the export performance of group-affiliated firms better or worse than that of unaffiliated companies? As outlined in section 2, the groups as paragons view, argues that group-affiliated firms may have a stronger internationalization propensity and higher export performance than unaffiliated companies (proposition 1a). On the other hand, the groups as parasites view, predicts that GAFs have lower export intensity than SAFs (proposition 1b).

The results in Table 3 provide clear support in favor of the latter theoretical approach and hypothesis: the estimated coefficient for the GAF variable turns out to be negative and significant in most of the regressions (with the exception of those for the smaller Central American sample reported in columns 4 and 7). Our estimations indicate therefore that group-affiliated companies in Latin America have on average lower export intensity than independent firms. This finding is in line with the empirical results of Hundley and Jacobson (1998), who analyzed export activities of Japanese firms 
affiliated to the six major keiretsu, and Gubbi et al. (2009), who investigated a panel of Indian firms in the pharmaceuticals sector.

To refine this result, we have also introduced some interaction variables in order to test how this average pattern differs between South American and Central American countries, and between manufacturing and service industries. Columns 2, 3 and 4 present separate estimations for South America and Central America, and indicate that while the main result of a lower export intensity of GAFs is strong and significant in the former sample, the estimated GAF coefficient is not significant in the latter. This may be related to the different characteristics and capabilities of exporting firms in Central America vis-a-vis larger and more established markets in South America, which was also pointed out by the results for some of the control variables discussed above. But the lack of statistical precision for the results for Central America may also be due to the relatively small size of the sample that it is available for these regressions compared to the larger South American dataset.

Further, regressions 5, 6 and 7 interact the GAF dummy with a dummy for manufacturing and service sectors, respectively. The results of these tests indicate that GAFs have lower export intensity than SAFs in both manufacturing and service industries, but the difference between GAFs and SAFs' export performance is much stronger for the service sectors. Manufacturing sectors are typically considered as "tradable" and more exposed to international competition, while services are often regarded as "non-tradable" sectors and mainly oriented to domestic markets rather than international sales. So, the difference between GAFs and SAFs' export intensity may be stronger in services than in manufacturing because of the lower internationalization propensity of service firms, in general, and also because of the great presence of business groups within the service industries, in particular.

On the whole, the results presented in this section provide clear support for the hypothesis of the groups as parasites view arguing that GAFs have lower export intensity than SAFs (proposition 1b). However, as outlined in section 2, the negative relationship between group affiliation and export performance may be explained by different mechanisms, and our empirical analysis is not able to point out exactly which of the relevant factors plays a more relevant role for the case of South and Central American companies investigated in this paper. Basically, as previously outlined in section 2.2, a negative relationship between affiliation and export intensity may arise because of three different reasons: (1) either because GAFs have a lower capability to engage in international activities than SAFs; (2) or because affiliated companies have a minor propensity (willingness, interest) to internationalize; (3) or, by contrast, because GAFs are actually highly engaged in international activities, but their preferred mode of entry into foreign markets is through FDI instead of export sales. 
Among these different explanations, the first one would seem to be not plausible and not in line with much of the empirical evidence in the literature on business groups in emerging economies. Some of the recent literature in this field does in fact point out that GAFs have on average a greater innovative capability than SAFs (see also Mahmood and Mitchell, 2004; Castellacci, 2013a), and on this basis it would be difficult to argue that they lack the capability to internationalize. The second explanation that groups have a minor propensity to internationalize because the benefits of affiliation are mostly related to domestic markets and networks seems to us more reasonable, well-founded, and clearly in line with the literature on business groups as networks, which is particularly relevant in the Latin American context. Carney et al. (2011) do also find that GAFs are more domestically-oriented than standalone firms. Finally, the third possible explanation - that GAFs' preferred mode of entry into foreign markets is through FDI rather than export - is also plausible and well in line with the recent literature on firm heterogeneity and international trade (Helpman et al., 2004).

In short, our summary interpretation of the empirical results presented in this section is that GAFs have lower export propensity than SAFs because of two distinct (but not incompatible) reasons: first, because they have in general a lower internationalization propensity; and, secondly, because those groups that seek to internationalize their activities prefer to do it through FDI rather than export sales.

\section{Conclusions}

When developing economies undertake a process of institutional transition and trade liberalization, domestic business enterprises experience new opportunities as well as new challenges. The recent literature in international economics and international business studies points out that firms' responses to market liberalization differ substantially. Some companies, endowed with superior resources and capabilities manage to reap the benefits of international competition, whereas other firms, with a weaker set of resources and capabilities, are not able to maintain their market position in a more open and competitive environment, and tend to gradually shrink and loose market shares. The present work has investigated this issue by focusing on the role of group affiliation for the export performance of business enterprises. The study has carried out an empirical analysis of the relationship between affiliation and export intensity of firms in Latin America, comparing in particular Central American countries to the larger group of South American economies.

The paper leads to two general conclusions. The first refers to the role of firm-specific resources and capabilities, and how these affect enterprise export activities in Latin America. In line with much of the recent literature, 
our empirical analysis confirms that firms' response to trade liberalization differs. The results indicate that companies with a greater size, product quality and specialization, and better ICT infrastructures have on average higher export intensity than most other firms in the same markets. When comparing these patterns between Central America and the broader Latin American sample, we also find that firm size, product quality and ICT infrastructures are much more important factors explaining export success for companies in Central America.

The second conclusion refers precisely to the role of group affiliation on export performance. The results clearly indicate that group-affiliated firms have lower export intensity than standalone companies. One possible reason explaining this pattern may be that GAFs have a lower internationalization propensity and greater domestic orientation than SAFs. A second related reason may instead be that, to the extent that they seek to internationalize their activities, business groups prefer to do so through an FDI rather than an export entry mode. Our results also point out that this pattern is much stronger for the South American sub-sample, whereas the patterns for Central America are not significant and should be interpreted with caution. Further, we also find that the difference between GAFs and SAFs export intensity is much stronger in the service sectors, industries in which Latin American business groups have actively been investing in recent years.

On the whole, these results provide support to the groups as parasites theoretical view, which emphasizes the negative consequences that groups have for economic development. Since export is a major channel of corporate growth at the micro level, and national GDP growth at the macro level, business groups' underperformance in export activities has the effect to hamper and slow down the process of export-led growth and economic development in Latin American economies.

A general implication of this study is that competition policy should be combined with trade liberalization and openness policies. At the same time as developing economies undertake a process of institutional transition and market liberalization, competition policies should be developed in order to regulate the activities of business groups, limit their market power, decrease entry barriers for new entrants, and in this way enhance domestic welfare by ensuring the functioning of openly competitive markets. 


\section{References}

Aulakh, P.S., Kotabe, M., Teegen, H., 2000. Export Strategies and Performance of Firms from Emerging Economies: Evidence from Brazil, Chile and Mexico. The Academy of Management Journal 43, 342-361. doi:10.2307/1556399

Bastos, P., Silva, J., 2012. Networks, Firms and Trade. Journal of International Economics 87, 352-364. doi:10.1016/j.jinteco.2011.12.011

Belderbos, R., Sleuwagen, L., 1996. Japanese Firms and the Decision to Invest Abroad: Business Groups and Regional Core Networks. The Review of Economics and Statistics 78, 214-220. doi:10.2307/2109923

Bull, B., Castellacci, F., Kasahara, Y., 2014. Business Groups and Transnational Capitalism in Central America: Economic and Political Strategies. Palgrave Macmillan, Hampshire. doi:10.1057/9781137359407

Carney, M., Gedajlovic, E., Heugens, P., Van Essen, M., Van Oosterhout, J., 2011. Business Group Affiliation, Performance, Context, and Strategy: A Meta-Analysis. Academy of Management Journal 54, 437-460. doi:10.5465/AMJ.2011.61967812

Casella, A., Rauch, J.E., 2002. Anonymous Market and Group Ties in International Trade. Journal of International Economics 58, 19-47. doi:10.1016/S0022-1996(01)00160-X

Castellacci, F., 2013a. Institutional Voids or Entry Barriers? Business Groups, Innovation and Market Development in Emerging Economies. NUPI Working Paper, 809.

Castellacci, F., 2013b. Service Firms Heterogeneity, International Collaborations and Export Participation. Journal of Industry, Competition and Trade 14, 259-285. doi:10.1007/s10842-013-0153-1

Castellacci, F., 2013c. Service Innovation and the Proximity-Concentration Trade-Off Model of Trade and FDI. Economics of Innovation and New Technology 23, 92-108. doi:10.1080/10438599.2013.828890

Ekholm, K., Forslid, R., Markusen, J., 2003. Export-Platform Foreign Direct Investments. NBER Working Paper 9517.

Gubbi, S., Aulakh, P.S., Ray, S., 2009. Do Business Groups Facilitate or Constrain Affilates' Adaptation to Institutional Transitions in Developing Economies? Academy of Management Best Paper Proceedings 2009. 
Guillen, M.F., 2000. Business Groups in Emerging Economies: A Resource-Based View. The Academy of Management Journal 43, 362-380. doi:10.2307/1556400

Granovetter, M., 1995. Coase Revisited: Business Groups in the Modern Economy. Industrial and Corporate Change 4, 93-130. doi:10.1093/icc/4.1.93

Hannan, M.T., Freeman, J.H., 1989. Organizational Ecology. Harvard University Press, Cambridge, MA.

Helpman, E., Melitz, M.J., Yeaple, S.R., 2004. Export Versus FDI with Heterogeneous Firms. American Economic Review 94, 300-316. doi:10.1257/000282804322970814

Hundley, G., Jacobson, C.K., 1998. The Effects of the Keiretsu on the Export Performance of Japanese Companies: Help or Hindrance? Strategic Management Journal 19, 927-937. doi:10.1002/(SICI)10970266(199810)19:10<927::AID-SMJ989>3.0.CO;2-1

Jean, R.B., Tan, D., Sinkovics, R.R., 2011. Ethnic Ties, Location Choice, and Firm Performance in Foreign Direct Investment: A Study of Taiwanese Business Groups FDI in China. International Business Review 20, 627-635. doi:10.1016/j.ibusrev.2011.02.012

Johanson, J., Vahlne, J.E., 1977. The Internationalization Process of the Firm: A Model of Knowledge Development and Increasing Foreign Market Commitments. Journal of International Business Studies 8, 23-3. doi:10.1057/palgrave.jibs.8490676

Khanna, T., 2000. Business Groups and Social Welfare in Emerging Markets: Existing Evidence and Unanswered Questions. European Economic Review 44, 748-761. doi:10.1016/S0014-2921(99)00059-8

Khanna, T., Palepu, K., 1997. Why Focused Strategies May Be Wrong for Emerging Markets. Harvard Business Review 75, 41-51.

Khanna, T., Yafeh, Y., 2007. Business Groups in Emerging Markets: Paragons or Parasites. Journal of Economic Literature XLV, 331-372. doi:10.1257/jel.45.2.331

Lamin, A., 2006. The Effect of Business Group Affiliation on Firm Market and International Strategies, PhD Thesis, Carlson School of Management, University of Minnesota.

Leff, N., 1978. Industrial Organization and Entrepreneurship in the Developing Countries: The Economic Groups. Economic Development and Cultural Change 78, 661-674. doi:10.1086/451052 
Mahmood, I.P., Mitchell, W., 2004. Two Faces: Effects of Business Groups on Innovation in Emerging Economies. Management Science 50, 1348-1365. doi:10.1287/mnsc.1040.0259

Mahmood, I., Zhu, H., Zajac, E., 2011. Where Can Capabilities Come from? Network Ties and Capability Acquisition in Business Groups. Strateguc Management Journal 32, 820-848. doi:10.1002/smj.911

Mayer, T., Ottaviano, G., 2007. The Happy Few: The Internationalization of European Firms. Bruegel Blueprint Series, Volume III.

Melitz, M., 2003. The Impact of Trade and Intra-Industry Reallocations and Aggregate Industry Productivity. Econometrica 71, 1695-1725. doi:10.1111/1468-0262.00467

Morck, R., Wolfenzon, D., Yeung, B., 2005. Corporate Governance, Economic Entrenchment, and Growth. Journal of Economic Literature 43, 655720. doi:10.1257/002205105774431252

Penrose, E.T., 1959. The Theory of the Growth of the Firm. Oxford University Press, Oxford, UK.

Prahalad, C.K., Hamel, G., 1990. The Core Competence of the Corporation. Harvard Business Review 68, 79-91.

Rauch, J.E., 2001. Business and Social Networks in International Trade. Journal of Economic Literature 39, 1177-1203. doi:10.1257/jel.39.4.1177

Tan, D., Meyer, K., 2010. Business Groups' Outward FDI: A Managerial Resources Perspective. Journal of International Management 16, 154-164. doi:10.1016/j.intman.2010.03.006

Wernerfelt, B., 1984. A Resource-Based View of the Firm. Strategic Management Journal 5, 171-180. doi:10.1002/smj.4250050207

Williamson, O., 1975. Market and Hierarchies: Analysis and Antitrust Implications. Free Press, New York. 


\section{Appendix: Definition and Measurement of Busi- ness Group}

The literature does not provide a clear and unequivocal definition of what a business group is. There exist several different definitions, and empirical studies have made use of a variety of distinct strategies to identify and measure group affiliation (Khanna and Rivkin, 2001; Khanna and Yafeh, 2007). Most studies, however, point out that business groups have three typical characteristics: (1) they are formed by legally independent firms; (2) there exist stable (long-term) relationships among affiliated companies; (3) group-affiliated firms are all subject to some sort of common ownership and control, e.g. through the coordination carried out by the headquarter (or by the family leading the group).

The variable that we have used in this study to measure group affiliation reflects well these three characteristics. As indicated in section 3, GAF is a dummy variable indicating whether an enterprise is part of a domestic group. This indicator has been obtained by interacting (multiplying) two dummy variables of the WBES questionnaire: (i) the one indicating whether "the firm is owned by private domestic individuals, companies or organizations"; (ii) the one reporting whether "the establishment is part of a larger firm" (question A.7). Notice that the term "establishment" used by the WBES survey is somewhat ambiguous. The WBES Questionnaire Manual (available at www.enterprisesurveys.org) states that "for the purposes of this survey an establishment must make its own financial decisions and have its own financial statements separate from those of the firm. An establishment must also have its own management and control over its payroll." (Questionnaire Manual, January 2011, p. 3). Elsewhere in the document, it is also pointed out that each establishment included in the survey is legally registered for tax purposes. This means that the survey question A.7 is appropriate to identify group-affiliated firms: it identifies companies (establishments) that are part of a larger firm, while at the same time being legally independent and having control of their financial and managerial decisions. In our sample of Latin American firms, this dummy variable indicates that around $12 \%$ of companies are GAFs. Out of these, $22 \%$ are headquarters without production and sales in their premises, $54 \%$ are headquarters carrying out also production and sales activities, and $24 \%$ are affiliated establishments that are physically separated from the headquarter.

In short, our definition and measurement of group affiliation corresponds to the three main characteristics that are typically highlighted in the literature: (1) the groups we identify are formed by legally independent companies; (2) all affiliated companies are linked together in a stable manner by means of headquarter-establishment links; (3) they are also subject to central coordination and control exercised by the headquarter leading the group. 